\section{An unusual presentation of deltamethrin poisoning}

Sir,

Patients presenting with intoxication comprise of an important part of emergency visits. Pyrethroids are widely used insecticides because they are about 2250 times more toxic to insects than mammals. ${ }^{[1]}$ The intoxications due to deltamethrin are rarely reported. We report a case of deltamethrin poisoning due to intentional oral ingestion as a suicidal attempt.

A 22-year-old female presented with nausea, vomiting, respiratory distress, altered sensorium, and 
generalized convulsions since $2 \mathrm{~h}$ to the emergency department of our institution. There was a history of around $50 \mathrm{ml}$ of deltamethrin ingestion $4 \mathrm{~h}$ prior to admission as revealed by attendants. Vital signs were: Pulse rate-120 bpm, blood pressure-100/60 mmHg, respiratory rate- $34 / \mathrm{min}$, and $\mathrm{SpO}_{2}$ (on oxygen through ventimask@61/min)-86\%. The chest was clear, body temperature was $37.4^{\circ} \mathrm{C}$, Glasgow coma scale $(\mathrm{GCS})=\mathrm{E}_{1} \mathrm{~V}_{1} \mathrm{M}_{3}$ and pupils were mid-dilated and sluggishly reacting to light. She was administered $5 \mathrm{mg}$ diazepam intravenously to control seizures, and tracheal intubation was carried out using modified rapid sequence induction. Investigations were: Blood glucose-110 mg/dl, blood urea- $28 \mathrm{mg} / \mathrm{dl}$, serum creatinine- $0.8 \mathrm{mg} / \mathrm{dl}$, serum sodium, potassium and chloride-140, 4, and $95 \mathrm{mmol} / \mathrm{L}$ respectively, serum calcium-8.6 mg/dl, lactate dehydrogenase-92 U/L, total bilirubin-0.9 mg/dl, SGOT/SGPT-30/32 U/L, and amylase-102 U/L. The patient was shifted to Respiratory Intensive Care Unit (RICU). Arterial blood gas (ABG) analysis: $\mathrm{pH}=7.39, \mathrm{paO}_{2}=98 \mathrm{mmHg}$, $\mathrm{paCO}_{2}=37.9 \mathrm{mmHg}, \mathrm{HCO}_{3}=20.9, \mathrm{SaO}_{2}=97 \%$. Electrocardiogram showed sinus tachycardia. The treatment comprised of injection furosemide $20 \mathrm{mg}$ $\mathrm{BD}$, sodium valproate $500 \mathrm{mg} \mathrm{BD}$, and midazolam infusion@ $1 \mathrm{mcg} / \mathrm{kg} / \mathrm{min}$. She was hemodynamically stable; respiratory efforts were present, but the poor GCS persisted.

After $2 \mathrm{~h}$ suddenly the heart rate increased from $80 \mathrm{bpm}$ to $140 \mathrm{bpm}$ for which injection metoprolol $5 \mathrm{mg}$ was administered intravenously butshe developed paroxysmal supraventricular tachycardia (PSVT) [Figure 1]. Injection adenosine $6 \mathrm{mg}$ intravenous (IV) was given, but PSVT was not settled, and $12 \mathrm{mg}$ IV was repeated. Possible causes were investigated and ruled out. The patient was afebrile, and an ABG with electrolytes was sent. The values were within normal limits. After 1-h, next episode of PSVT occurred which was accompanied by

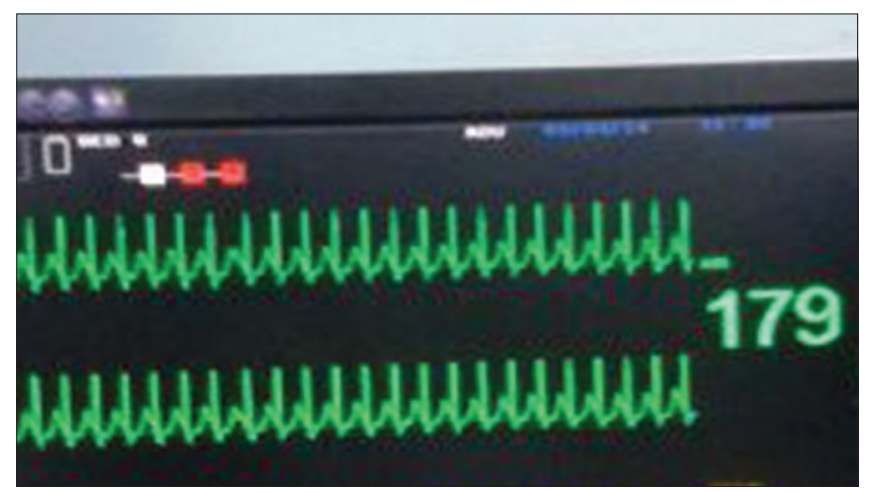

Figure I: Monitor showing paroxysmal supraventricular tachycardia hypotension. Electrical cardioversion was done, but the patient did not respond. Subsequently, she had a cardiac arrest and despite all resuscitative measures could not be salvaged.

Pyrethroids are of two types: Type I-altherin, resmethrin, and permethrin; and Type II-deltamethrin, cypermethrin, and fenvalerate. Both types impair the ion transport across voltage sensitive sodium channels by delaying their closure. Type II pyrethroids also depress the chloride currents through voltage-dependent chloride channels. ${ }^{[2]}$ At higher concentrations, they act on GABA-gated chloride channels resulting in seizure activity. ${ }^{[1]}$ Signs of poisoning are headache, irritability, ataxia, hyperexcitation, convulsions, and death. ${ }^{[3]}$ There is no specific antidote for pyrethroid poisoning per se, and the management is symptomatic and supportive. ${ }^{[4]}$

The cardiac toxicity with pyrethroids has not been reported yet. Though the seizures were controlled in RICU, but the possibility of nonconvulsive seizures cannot be negated as continuous electroencephalogram monitoring facility was not available at our center. Hence, neuroexcitation might have caused sympathetic surge leading to cardiac involvement. The other possibility could be the effect of deltamethrin on sodium channels of the myocardium causing delayed closure resulting in hyperexcitability. The exact mechanism, however, remains undefined.

To conclude, the inclusion of our case report to the literature provides new knowledge and information regarding poisoning due to deltamethrin, which will further aid intensivists in managing these patients.

\section{Financial support and sponsorship Nil.}

\section{Conflicts of interest}

There are no conflicts of interest.

$$
\begin{array}{r}
\text { Renu Bala, Navdeep Kaur, Arnab Bannerji, } \\
\text { Rashmi Virmani } \\
\text { Department of Anaesthesiology and Critical Care, } \\
\text { Pandit Bhagwat Dayal Sharma Post Graduate } \\
\text { Institute of Medical Sciences, UHS, Rohtak, } \\
\text { Haryana, India }
\end{array}
$$


Correspondence:

Dr. Navdeep Kaur,

House No. 423, Street No. 2, Gurdial Nagar, Sito Road,

Abohar - 152 116, Punjab, India.

E-mail: drmnavi126@gmail.com

\section{References}

1. Bradberry SM, Cage SA, Proudfoot AT, Vale JA. Poisoning due to pyrethroids. Toxicol Rev 2005;24:93-106.

2. Soderlund DM, Clark JM, Sheets LP, Mullin LS, Piccirillo VJ, Sargent D, et al. Mechanisms of pyrethroid neurotoxicity: Implications for cumulative risk assessment. Toxicology 2002;171:3-59.

3. Poonam S, Mysra J, Rambir S. Deltamethrin toxicity: A review. Ind J Biol Res 2013;2:91-107.

4. Flannigan SA, Tucker SB, Key MM, Ross CE, Fairchild EJ $2^{\text {nd }}$, Grimes BA, et al. Synthetic pyrethroid insecticides: A dermatological evaluation. Br J Ind Med 1985;42:363-72.

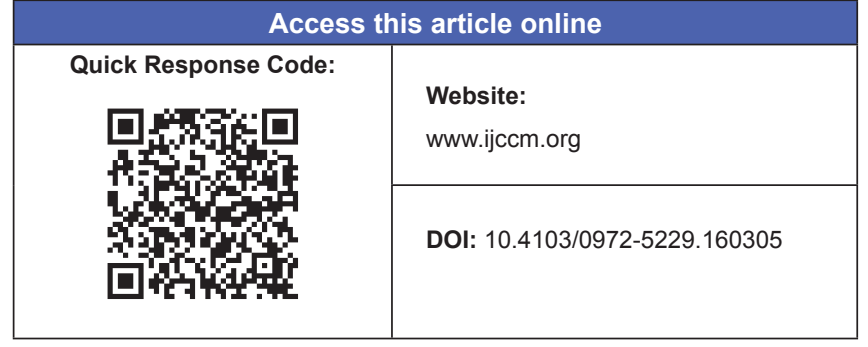

How to cite this article: Bala R, Kaur N, Bannerji A, Virmani R. An unusual presentation of deltamethrin poisoning. Indian J Crit Care Med 2015;19:435-7. 